\title{
Growth response of Spirulina platensis in papaya skin extract and antimicrobial activities of Spirulina extracts in different culture media
}

\author{
Nasima Akhtar ${ }^{\mathrm{a}}$, Monzur Morshed Ahmed ${ }^{\mathrm{a}}$, Nishat Sarker ${ }^{\mathrm{b}}$, Khandaker Rayhan Mahbub ${ }^{\mathrm{a}}$ \\ and Md. Abdul Matin Sarker ${ }^{\mathrm{a}}$ \\ ${ }^{a}$ Bangladesh Council of Scientific and Industrial Research (BCSIR), Dhaka, Bangladesh and ${ }^{b}$ Department of \\ Microbiology, Stamford University, Dhaka, Bangladesh
}

\begin{abstract}
Growth response of Spirulina platensis in papaya skin extract media and their antimicrobial activity were studied. Five different concentrations e.g. $10 \mathrm{gm} / \mathrm{L}, 8 \mathrm{gm} / \mathrm{L}, 6 \mathrm{gm} / \mathrm{L}, 4 \mathrm{gm} / \mathrm{L}$ and $2 \mathrm{gm} / \mathrm{L}$ of Papaya (Carica papaya) skin extract media and $\mathrm{BD}_{1}$ (control) medium were used in this study. After 8 days of cultivation, the optical density (0.33) was recorded in $\mathrm{BD}_{1}$ medium and among the five different concentrations of papaya skin extract media the maximum was found (0.31) in $6 \mathrm{gm} / \mathrm{L}$. Antimicrobial activity of Spirulina platensis grown in three media namely Zarrouk, $\mathrm{BD}_{1}$ media and media made from papaya skin extract was also studied. Only freeze dried Spirulina platensis powder extract showed inhibitory effect against bacteria and no antifungal activity was observed.
\end{abstract}

Key Words: Growth response, Antimicrobial activity, Papaya skin extract media, Spirulina platensis

\section{Introduction}

Spirulina platensis, a blue -green micro alga, has been used since ancient times as a source of food because of its high nutritional value (Dillon et al. 1995). It is rich in proteins, vitamins, minerals, carbohydrates and $\gamma$-linolenic acid. It is gaining more and more attention, not only for the foods aspects but also for the development of potential pharmaceuticals (Quoc and Pascaud, 1996). This alga is being widely studied, not only for nutritional reasons but also for its reported medicinal properties (Qureshi and Ali, 1996; Hayakawa et al., 1997; Kim et al., 1998; Miranda et al., 1998; Mishima et al., 1998; Hirahashi et al., 2002; Subhashini et al., 2004), antimicrobial activities (Demule et al., 1996; Ozdemir et al., 2004) as well as to inhibit the replication of several viruses, such as Herpes simplex and HIV-1 (Ayehunie et al., 1998; Hernandez-Corona et al., 2002). In Biological Research Division, BCSIR, Dhaka, Spirulina was cultured at pilot plant scale for over 19 years. Bangladesh medium (Jahan et al., 1994) was developed in this laboratory for commercial production of Spirulina in Bangladesh. Other medium $\mathrm{BD}_{2}, \mathrm{BD}_{3}, \mathrm{BD}_{4}$, and $\mathrm{BD}_{5}$ were developed in the same Laboratory for domestic scale culture of Spirulina in Bangladesh (Khatun et al., 2006). Bangladesh is an agrobased country. In Bangladesh, huge number of vegetable is growing which have nutritional value. If these nutritional vegetable wastes used as nutrient source for Spirulina cul- ture, it would be economically helpful. With a view to grow Spirulina at domestic level, research was aimed to develop a cheaper medium by utilizing locally available vegetable wastes such as skin of green papaya (Carica papaya) which contains necessary nutrients and mineral elements (Oloyede, 2005) which may be useful for growth of Spirulina platensis.

\section{Materials and Methods}

\section{Media preparation}

Fresh green papaya (Carica papaya) skin was peeled. Papaya skin was weighed and washed with tap water. $29 \mathrm{gm}$ papaya skin was blended in $200 \mathrm{ml}$ tap water. After blending, extract was sieved with $200 \mu$ mess cloth and stored at $+4^{\circ} \mathrm{C}$ until use. For preparation of different concentration of papaya skin extract media, tap water was added separately with stored extract to make $10 \mathrm{gm} / \mathrm{L}, 8 \mathrm{gm} / \mathrm{L}, 6 \mathrm{gm} / \mathrm{L}, 4 \mathrm{gm} / \mathrm{L}$ and $2 \mathrm{gm} / \mathrm{L}$ concentration and thoroughly mixed with $200 \mathrm{mg} / \mathrm{L}$ urea, $5 \mathrm{gm} / \mathrm{L} \mathrm{NaCl}$ and $3 \mathrm{gm} / \mathrm{L} \mathrm{NaHCO}_{3}$ to increase the concentration of nitrogen, salinity and $\mathrm{pH}$ respectively. $\mathrm{BD}_{1}$ medium (Jahan et al., 1994) was used as control for this experiment. Each experiment was done with 3 replicates. 


\section{Inoculum preparation and maintenance}

Culture was carried out in 1L conical flask. $500 \mathrm{ml}$ of papaya skin extract medium was given in each flask. Stock culture (Spirulina platensis) was collected from Biological Research Division, BCSIR, Dhaka which was maintained in Zarrouk (1966) medium. Equal amount of inoculums (20ml/L) was added into each flask (initial OD 0.11). The flasks were shaken everyday in the morning and evening. These were kept in a room near the window, exposed to natural condition. The optical density (OD) of the culture was recorded by Spectrophotometer (Type-Helios Gamma, NC-9423 UVG $1702 \mathrm{E}$ ) for the maintenance of the growth. $\mathrm{PH}$, temperature, light intensity, salinity and dissolved oxygen level of the culture were recorded. The condition of Spirulina culture was observed under compound microscope once a week and recorded.

\section{Sample preparation for screening of antimicrobial activity}

S. platensis was cultivated under photoautotrophic growth

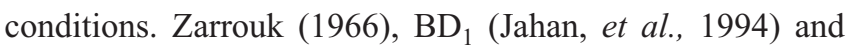
newly made Papaya Skin Extract media were used for cultivation. The initial $\mathrm{pH}$ was adjusted to 9.5 . The culture temperature was maintained at $30^{\circ} \pm 0.1{ }^{\circ} \mathrm{C}$. S. platensis was collected after 8 days of culture and dried in 3 different ways - freeze dry, sun dry and shade dry.

\section{Preparation of various extracts of $S$. platensis}

Freeze-dried, sun dried and shade dried S. platensis samples were mixed well with different solvents separately at the ratio of $0.5: 10 \mathrm{w} / \mathrm{v}$. Three different solvents (ethanol, methanol and chloroform) were used for the preparation of extracts of S. platensis. Twenty gram dried Spirulina powder was steeped separately in methanol and chloroform, 20gm dried powder was steeped in ethanol, then all the samples were kept for 72 hours at room temperature. Soaked mixtures were filtered (using What man filter paper-I). Then the filtrate was subjected to rotary vacuum evaporator (STUART, RE3022C) at $50^{\circ} \mathrm{C}$ and concentrated to gummy materials under reduced pressure. The gummy materials were then collected in small vials and then dried in room temperature. Thus crude extracts were obtained. The extracts were kept at $+4{ }^{\circ} \mathrm{C}$ until use. The gummy extracts were dissolved in dimethyl sulfo-oxide (DMSO) prior to use in antimicrobial activity test.

\section{Determination of antibacterial and antifungal activities}

In vitro antibacterial studies were carried out against four bacterial pathogens viz Salmonella typhi CRL.(ICDDR.B), Escherichia coli ATCC 25922, Staphylococcus aureus ATCC 25923 Bacillus cereus BTCC 19 and two fungal pathogens viz Aspergillus fumigatus DSM 819 and Candida albicans ATCC 10239 which were obtained from the Microbiology Laboratory of IFST, BCSIR, Dhaka. Bacterial inoculums were prepared by Clinical and Laboratory Standards Institute (CLSI) guideline. Bacterial cultures were emulsified in normal saline and turbidity was matched with 0.5 McFarland turbidity standard. The agar cup method (Barry, 1980) was followed to investigate the antibacterial activity of the extracts. Wells of $6 \mathrm{~mm}$ diameter was punched over the agar plates using a sterile cork borer. The bottoms of the wells were sealed by pouring $50-100 \mu 1$ of molten MHA into the scooped out wells. Using a micropipette, extracts of different solvents were added to different wells in the inoculated plate. These plates were then kept at $4^{\circ} \mathrm{C}$ for 2-4 hours and then incubated at $37{ }^{\circ} \mathrm{C}$ for 24 hours. Inhibition zones around the wells confirm the antibacterial activity of the respective extracts.

The poisoned food technique (Grover and Moore, 1962) was used to screen antifungal activity. $0.1 \mathrm{ml}$ extract of Spirulina platensis in respective solvent was taken by sterilized pipette in a sterile petriplate and then $20 \mathrm{ml}$ of Sabouraud dextrose agar medium was poured into the petriplate, mixed well and allowed to solidify. Inoculation was done at the centre of each plate with $5 \mathrm{~mm}$ mycelium block for fungus. The mycelium block was prepared with the help of cork borer from the growing area of a 5 days old culture of the test fungi on sabouraud dextrose agar. The inoculated plates were incubated at $25^{\circ} \mathrm{C} \pm 2$ for 3 to 5 days. After 5 days of incubation the diameter of fungal radial mycelia growth was measured. The average of three measurements was taken as redial mycelial growth diameter of the fungus in $\mathrm{mm}$. The percentage inhibition of mycelia growth of the test fungus was calculated by following method:

$\mathrm{I}=(\mathrm{C}-\mathrm{T}) / \mathrm{C} \times 100 . \quad$ Here, $\mathrm{I}=$ Percentage of inhibition, $\mathrm{C}=$ Diameter of the fungal colony in control, $\mathrm{T}=$ diameter of the fungal colony in treatment.

\section{Result and Discussion}

Generally Spirulina platensis are spiral shaped. Straight filaments have better survival capacity, and under less favor- 
able conditions coiled filaments turn straight (Noor et al., 2008). During initial growth period the maximum filaments condition were found to be straight, but after 14 days most of the filaments were turned to spiral shape in $6 \mathrm{gm} / \mathrm{L}$ papaya skin extract media. The effect of papaya skin extract media on morphological condition of Spirulina platensis are presented in the Table I and Fig 1.

Table I: Effect of papaya skin extract media on morphology of Spirulina platensis (6gm/L)

\begin{tabular}{ll}
\hline Time period & Conditions (Average of 18 observations) \\
\hline Day 0 & $\begin{array}{l}\text { Filaments are very good and healthy, some } \\
\text { are in spiral shaped and some are in } \\
\text { straight shaped and light blue- green in } \\
\text { color. }\end{array}$ \\
After 8 days & $\begin{array}{l}\text { Some filaments are in spiral shaped, some } \\
\text { are in broken condition and numbers of fil- } \\
\text { aments were more than previous observa- } \\
\text { tion and light blue green in color. }\end{array}$ \\
After 14 days & $\begin{array}{l}\text { Number of filaments were less than previ- } \\
\text { ous observation and maximum filaments } \\
\text { are in spiral shaped and light blue-green in } \\
\text { color. }\end{array}$ \\
\hline
\end{tabular}

different Spirulina strain is between $30-35^{\circ} \mathrm{C}$ with $40^{\circ} \mathrm{C}$ definitely injurious.

Venkataraman (1983) stated that even a short exposure of Spirulina cultures to direct intense sunlight will result in bleaching of algal cells. In this respect, experimental flasks were kept at room temperature near the window and light intensity was 120 Lux to 2.5 Klux. The range of dissolved oxygen level was $1-4 \mathrm{mg} / \mathrm{L}$. Salinity of the culture medium was 10 ppt. Salinity plays a direct role on the purity of the culture Bonin (1992). Fig. 2 shows the growth of Spirulina platensis in the experimental culture media. Despite having started with a similar initial inoculum, the growth of Spirulina platensis was started to change from the second day of cultivation. After 8 days of cultivation, the highest OD 0.33 was observed in control media $\mathrm{BD}_{1}$, whereas $\mathrm{OD}$ $0.31,0.28,0.20,0.19$ and 0.18 was observed in concentration $6,4,2,8$ and 10 of papaya extract media, respectively. It was observed that after 8 days of cultivation, optical density was decreased in experimental medium except concentration 2 of papaya extract medium. Papaya skin extract culture media of concentration 6, yielded $500 \mathrm{mg} / \mathrm{l}$ of Spirulina platensis per 8 days whereas control medium, $\mathrm{BD}_{1}$ yielded $750 \mathrm{mg} / \mathrm{L}$. In $\mathrm{BD}_{3}$ and $\mathrm{BD}_{4}$ media, yield was $664 \mathrm{mg} / \mathrm{l}$ and $665 \mathrm{mg} / \mathrm{l}$, respectively (Begum et al., 1998).

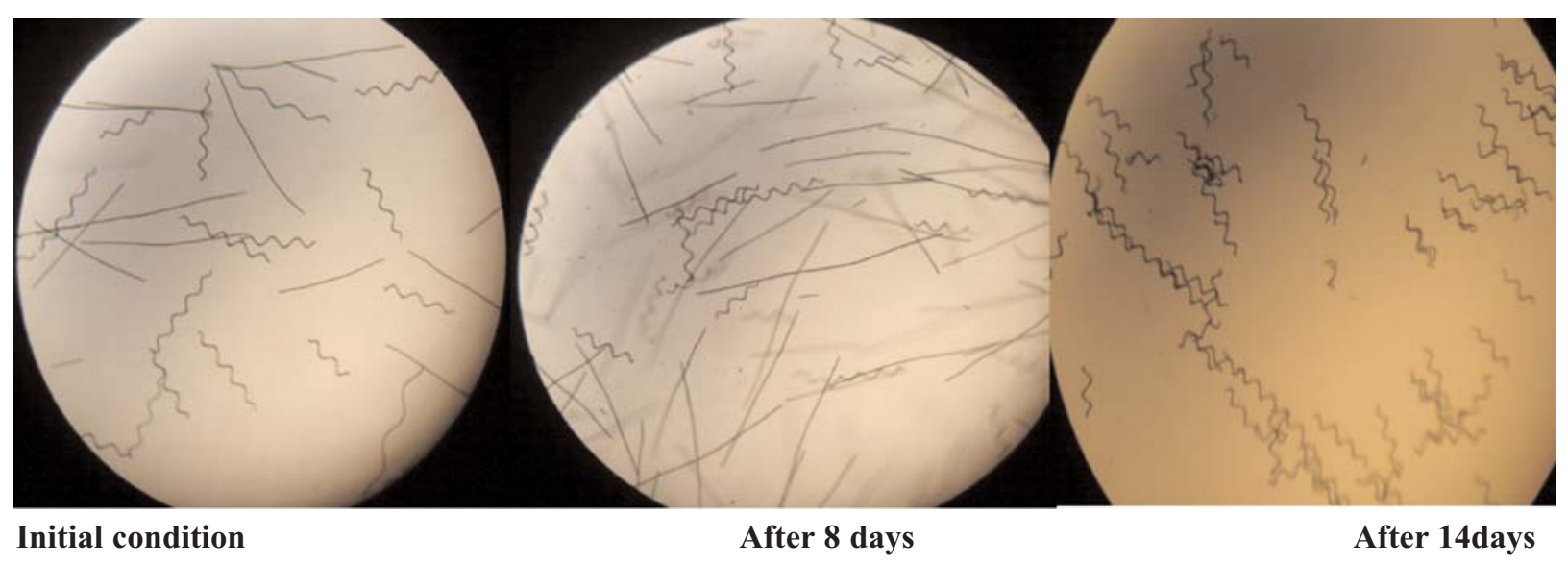

Fig. 1: Microscopic view of Spirulina platensis cultured in $6 \mathrm{gm} / \mathrm{L}$ Papaya skin extract media

Spirulina requires relatively high $\mathrm{pH}$ values between 9.5-9.8 Bonnin (1992). In the experimental papaya skin extract media $\mathrm{pH}$ was varied from 9.4 to 9.8 (Table II). During experimental period, the range of temperature of the culture medium was found between $27.4^{\circ} \mathrm{C}$ and $30.4^{\circ} \mathrm{C}$. Richmond (1992), reported that the optimal temperature for growth of

\section{Antimicrobial activity of Spirulina platensis}

In this experiment, different solvent extracts of Spirulina platensis were screened for their antimicrobial activity. Only freeze dried powder extracts showed antibacterial activity against four pathogenic bacteria viz Salmonella typhi, 
Table II: pH of the experimental media (Average of triplicates)

\begin{tabular}{lcccccccc}
\hline $\begin{array}{l}\text { Different } \\
\text { concentrations } \\
\text { ns }(\mathrm{gm} / \mathrm{L})\end{array}$ & $\begin{array}{c}\text { Initial } \\
\mathrm{pH}\end{array}$ & $\begin{array}{c}\text { After 2 } \\
\text { days }\end{array}$ & $\begin{array}{c}\text { After 4 } \\
\text { days }\end{array}$ & $\begin{array}{c}\text { After 6 } \\
\text { days }\end{array}$ & $\begin{array}{c}\text { After 8 } \\
\text { days }\end{array}$ & $\begin{array}{c}\text { After 10 } \\
\text { days }\end{array}$ & $\begin{array}{c}\text { After 12 } \\
\text { days }\end{array}$ & $\begin{array}{c}\text { After 14 } \\
\text { days }\end{array}$ \\
\hline Conc. 2 & 9.5 & 9.6 & 9.6 & 9.7 & 9.8 & 9.8 & 9.8 & 9.7 \\
Conc. 4 & 9.4 & 9.6 & 9.6 & 9.6 & 9.7 & 9.8 & 9.7 & 9.7 \\
Conc. 6 & 9.7 & 9.6 & 9.5 & 9.6 & 9.6 & 9.7 & 9.7 & 9.6 \\
Conc. 8 & 9.7 & 9.5 & 9.5 & 9.5 & 9.5 & 9.6 & 9.7 & 9.7 \\
Conc. 10 & 9.5 & 9.3 & 9.3 & 9.5 & 9.5 & 9.5 & 9.7 & 9.6 \\
Control medium, $\mathrm{BD}_{1}$ & 9.4 & 9.6 & 9.6 & 9.6 & 9.7 & 9.8 & 9.9 & 9.8 \\
\hline
\end{tabular}

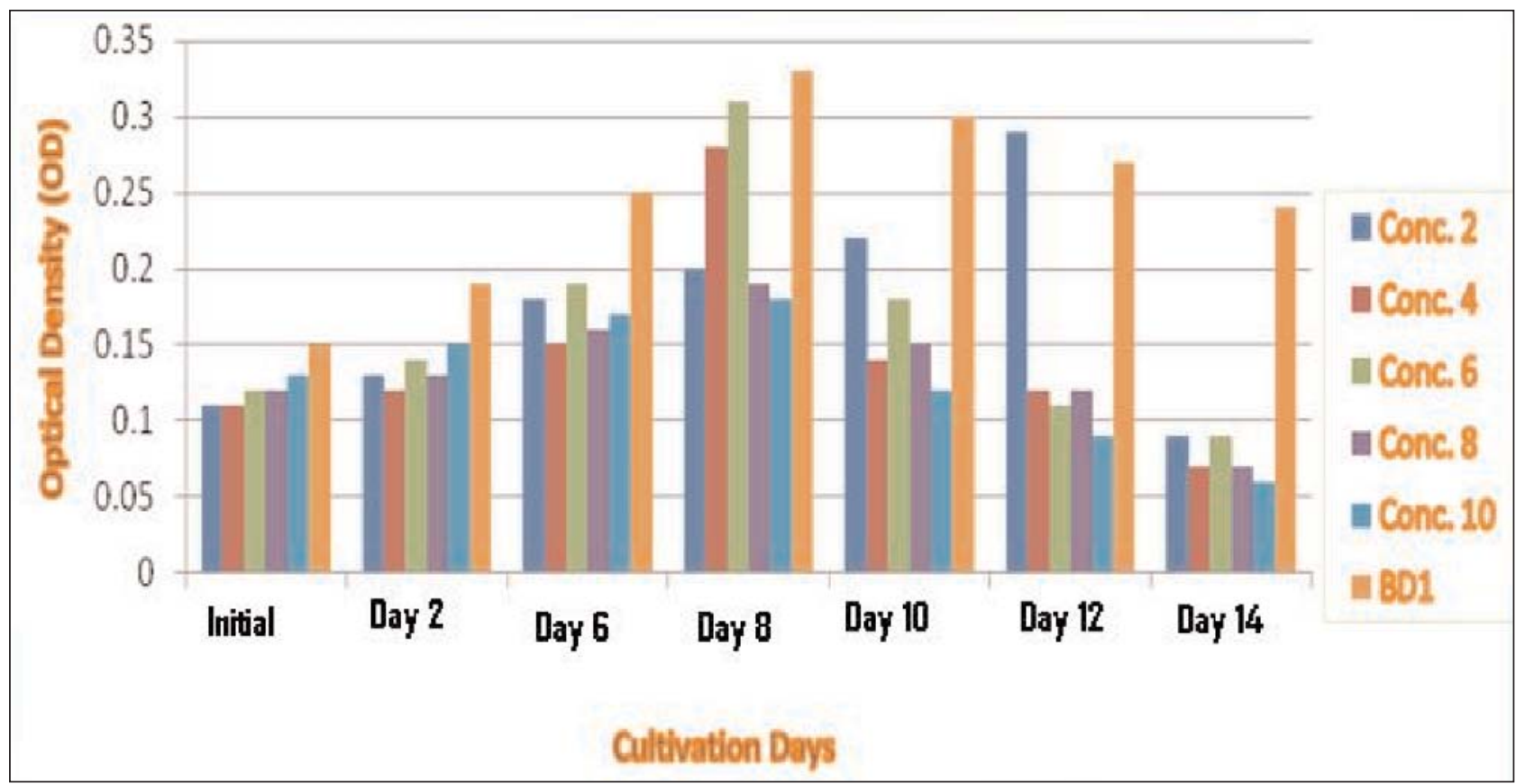

Fig. 2: Bar graph showing the growth of Spirulina platensis in experimental culture media (papya skin extract and $\mathrm{BD}_{1}$ media)

Escherichia coli, Staphylococcus aureus and Bacillus cereus. Antifungal activity was not observed by any type of powder extracts. Concerning the antibacterial effects, methanol extracts of Spirulina platensis (cultured in IFP media) gave the highest zone of inhibition $(20 \mathrm{~mm})$ against Bacillus cereus (Table III). Staphylococcus aureus was the second most inhibited bacteria with most of the extracts of Spirulina platensis (cultured in $\mathrm{BD}_{1}$ media). The growth of Salmonella typhi was moderately inhibited and Escherichia coli was partially inhibited by all extracts of Spirulina platensis (cultured in IFP media). It is clear from the Table III that the diameter of the inhibition zone depends mainly on types of the powder, type of solvents used, amount of extracts used and the tested bacterial organisms. In different studies, freeze dried extracts of $S$. platensis have shown antimicrobial activity against pathogenic bacteria. They have also reported that the extracts extracted in different solvents were effective against both Gram-positive and Gram negative organisms (Ozdemir et al., 2004; Kaushik and Chauhan, 2004; Bhowmik et al., 2009). This is in agreement with our findings, since the $S$. platensis extracts had effects on both types of bacteria used in this study. 
Table III: Inhibition zone activities of freeze dried Spirulina platensis cultured from different media on four species of bacterial growth

\begin{tabular}{|c|c|c|c|c|c|c|c|c|c|}
\hline \multirow[t]{3}{*}{ Name of the organism } & \multicolumn{9}{|c|}{ Zone of Inhibition in $\mathrm{mm}$} \\
\hline & \multicolumn{3}{|c|}{ Chloroform } & \multicolumn{3}{|c|}{ Ethanol } & \multicolumn{3}{|c|}{ Methanol } \\
\hline & $\mathrm{BD}_{1}$ & IFP & PSEM & $\mathrm{BD}_{1}$ & IFP & PSEM & $\mathrm{BD}_{1}$ & IFP & PSEM \\
\hline Salmonella typhi & 7 & 12 & 8 & 7 & 12 & 8 & 8 & 13 & 8 \\
\hline Staphylococcus aureus & 14 & 8 & 7 & 14 & 8 & 7 & 15 & 9 & 8 \\
\hline Bacillus cereus & 9 & 17 & 8 & 10 & 19 & 9 & 12 & 20 & 10 \\
\hline Escherichia coli & - & 9 & 7 & - & 8 & 7 & 8 & 8 & 7 \\
\hline
\end{tabular}

(-) indicates no zone of inhibition

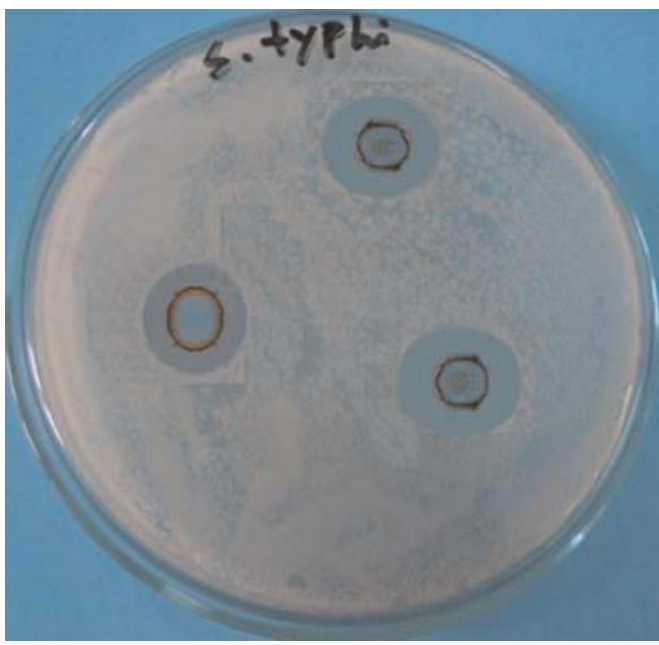

Fig. 3: Antimicrobial activity of Spirulina platensis cultured in IFP media against Salmonella typhi

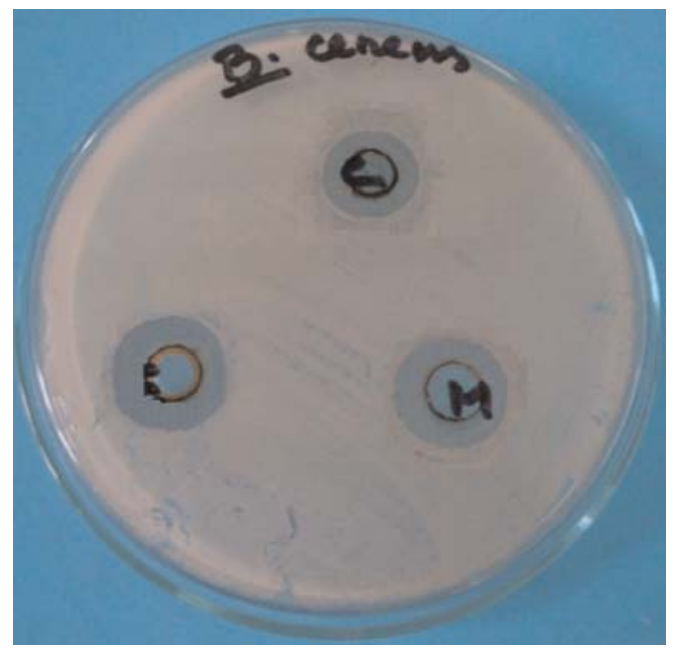

Fig. 4 : Antimicrobial activity of Spirulina platensis cultured in IFP media against Bacillus cereus

\section{Conclusion}

The present study suggests that vegetable wastes can be used as a good source of nutrititive media for Spirulina culture at domestic level. Active ingredients present in S. platensis have diverse biological activity. Identification of these active ingredients present in S. platensis may be interesting topic to study antimicrobial activity of $S$. platensis.

\section{References}

Ayehunie S, Belay A, Baba TW and Ruprecht RM 1998. Inhibition of HIV-1 replication by an aqueous extract of Spirulina platensis (Arthrospira platensis). Journal of Acquired Immune Deficiency Syndromes and Human Retrovirology, 18: 7-12.

Barry AL 1980. Procedure for testing antimicrobial Agents in Agar media. In: Antibiotics in Laboratory Medicine. Lorin V (eds), Williams Wilkins Co. Baltimore: USA, pp.1-23.

Begum S, Noor P, Akhtar N and Majid FZ 1998. Spirulina culture in Bangladesh VI. Domestic production of Spirulina. Bang. J. Sci. and Ind. Res., 33 (3): 473-478.

Bhowmik Dola, Dubey Jaishree and Mehra Sandeep 2009. Probiotic Efficiency of Spirulina platensis Stimulating Growth of Lactic Acid Bacteria. World Journal of Dairy \& Food Sciences 4 (2): 160-163.

Bonnin G 1992. Spirulina Production Engineering Handbook, B.E.C.C.M.A., A-5 place Roger Salengro 4400 Nantes France. 79.

Demule MCZ, Decaire GZ and Decano MS 1996. Bioactive substances from Spirulina platensis (Cianobacteria). International Journal of Experimental Botany, 58: 93-96. 
Dillon JC, Phuc AP, Dubacq JP 1995. Nutritional value of the alga Spirulina. World Review of Nutrition and Dietetics, 77. Washington: 32-46.

Grover RK and JD Moore 1962. Toximetric studies of fungicides against brown rot organism. Sclerotina fruticola. Phytopathology. 52: 876-880.

Hayakawa Y, Hayashi T, Hayashi K, Ozawa T, Niiya K and Akugawa N 1997. Calcium Spirulan as an inducer of tissue-type plasminogen activator in human fetal lung fibroblasts. Biochimica Biophysica Acta, 1355: 241247.

Hernadez-Corona A, Nieves I, Meckes M, Chamorro G. and Barron BL 2002. Antiviral activity of Spirulina maxima against herpes simplex virus type 2. Antiviral Research, 56: 279-285.

Hirahashi T, Matsumoto M, Hazeki K, Saeki Y, Ui M and Seya T 2002. Activation of the human innate immune system by Spirulina augmentation of interferon.

Jahan MAA, Noor P, Akhtar N 1994. Spirulina culture in Bangladesh 111.Developement of a Medium, suitable for commercial cultivation of Spirulin in Bangladesh. B.J. S.I.R. 2 (4). 149.

Kaushik P and Chauhan A 2007. In vitro antibacterial activity of laboratory grown culture of Spirulina platensis. Indian J. Microbiol. 48:348-352.

Khatun R, Noor P, Akhtar N, Jahan MAA, Hossain M and Munshi JL 2006. Spirulina Culture in Bangladesh XI Selection of a Culture Medium, Suitable for Culturing a Local Strain of Spirulina. Bang. J. Sci. Ind. Res. 41(3-4): 227-234.

Kim HM, Lee, EH and Moon YH 1998. Inhibitory effect of mast cell-mediated immediate-type allergic reactions in rats by Spirulina. Biochemica Pharmacology, 55: 1071-1076.

Miranda MS, Cintra RG, Barros SB and Manchini FJ 1998. Antioxidant activity of the microalga Spirulina maxima. Brazilian Journal of Medical Biology Research, 31: 1075-1079.

Mishima T, Murata J, Toyoshima M, Fujii H, Nakajima M, Hayashi T, Kato T and Saiki I 1998. Inhibition of tumor invasion and metastasis by calcium spirulan
(Ca-SP), a novel sulfated polysaccharide derived from a blue-green alga, Spirulina platensis. Clinical and Experimental Metastasis, 16: 541-550.

Noor P, Akhtar N, Begum S and Munshi JL 2008. Spirulina Culture in Bangladesh XII. Effects of Different Culture Media, Different Culture Vessels and Different Cultural Conditions on Coiled and Straight Filament Characteristics of Spirulina. Bang. J. Sci. Ind. Res. 43(3), 369- 376.

Oloyede OI 2005. Chemical Profile of Unripe Pulp of Carica papaya. Pakistan Journal of Nutrition 4(6): 379-381.

Ozdemir G, Karabay NU, Dalay M C and Pazarbasi B 2004. Antibacterial activity of volatile components and various extracts of Spirulina platensis. Phytotherapy Research, 18: 754-757.

Quoc K P and Pascaud M 1996. Effects of dietary gammalinolenic acid on the tissue phospholipid fatty acid composition and the synthesis of eicosanoids in rats. Annals of Nutrition and Metabolism, 40: 99-108.

Qureshi MA and Ali RA 1996. Spirulina platensis exposure enhances macrophage phagocytic function in rats. Immunopharmacology and Immunotoxicology, 18: 457-463.

Richmond A 1992. Mass culture of cyanobacteria. In: Mann, N, Carr, N, Eds. Photosynthetic prokaryotes. 2nd ed. Plenum Press, New York and London. pp. 181-210

Subhashini J, Mahipal SVK, Reddy MC, Reddy MM, Rachamallu A and Reddanna P 2004. Molecular mechanisms in C-Phycocyanin induced apoptosis in human chronic myeloid leukemia cell line-K562. Biochemical Pharmacology, 68: 453-462.

Venkataraman LV 1983. Blue green alga Spirulina. Central food technological research institute, India; pp. 3-74.

Zarrouk 1966. Contribution a I 'etude dune cyanophycee; Influence de divers facteurs physiques et chimiques sur Ia croissance et Ia photosynthese de Spirulina maxima (Setch et Gardner0 Geitler; Thesis, University of Paris.

Manuscript received on 20 December 2010; revised on 25 July 2011; accepted on 24 October 2011. 